\title{
Developing Blended Learning With the Use of I-Learn in Block 1.A (Introduction to Midwifery Education)
}

\author{
Rafika Oktova ${ }^{1 *}$ Laila Rahmi $^{2}$ \\ ${ }^{1}$ Bachelor of Midwifery, Medical of Faculty, Andalas University \\ ${ }^{2}$ Bachelor of Midwifery, Medical of Faculty, Andalas University \\ *Corresponding author. Email: rafikamkeb@gmail.com
}

\begin{abstract}
Blended learning is a development of the e-learning model, which combines face-to-face learning models with online learning. With the existence of blended learning allows lecturers to provide a more comprehensive learning experience for students, increase access and convenience for students in accessing learning materials, improve the quality of learning and reduce learning costs. Application of models of blended learning from aspects of accessibility, allowing lecturer to distribute learning materials and instructional media are online so that it can be accessed by students anywhere and anytime with an internet connection, access can be done via a laptop or via a smartphone. The adoption of the blended learning model from the aspect of learning quality, improves student experience through learning media in the form of text, audio, video, animation, or through online discussion forums. The learning method in Midwifery Undergraduate Study Progam is a Student Centered Learning (SCL). Guaranting and improving the quality of graduate midwife to do through several efforts, including the development of midwifery education based learning system that blended learning is done on block 1.A with entitled introduction to midwifery education is a block that must be learned by the students of the first semester in Midwifery Study Program, Faculty of Medicine, Andalas University.
\end{abstract}

Keywords: Development, Blended Learning, I-learn

\section{INTRODUCTION}

The direction of developing educational technology today does not only focus on cognitive development but also emphasizes the development of affective abilities and attitudes. Therefore, it is necessary to develop a learning model that is able to cover more comprehensive aspects. Limited time and access to learning materials are certainly not a major obstacle in improving student quality. By using a blended learning model that combines online learning and face to-face learning, the effectiveness of learning can be achieved with good evaluation results ${ }^{1}$.

One of the efforts to guarantee and improve the quality of midwife graduates is the development of system based midwifery education with blended learning to improve performance and be able to adapt the main competencies of midwives and have a broad range of knowledge insights.
The term blended learning is known as the concept of hiprida learning that combines face-to-face, online and offline learning. Blended means a mixture or combination and learning means pembelajaran ${ }^{2}$. According to Musa, blended learning is to combine learning is e-learning or online with face-to-face learning. Online learning by making use of internet network which consists of web based learning. This blended learning is a combination of multimedia based technology development, CD ROM, video streaming, email, voice mail, etc by combining faceto-face learning in class ${ }^{3}$.

Blended learning is a development of the e-learning model. With the existence of blended learning allows lecturers to provide a more comprehensive learning experience for students, increase access and convenience for students in accessing learning materials, improve the quality of learning and reduce learning costs. In blended learning can combine face-to- face learning model with learning online. In terms of 
accessibility, the application of the blended learning model allows lecturers to distribute learning materials and learning media online so that students can access them anywhere and anytime with an internet connection, access can be done via a laptop or via a smartphone. For the quality of learning, the application of the learning model improves the student experience through learning media in the form of text, audio, video, animation, or through online discussion forums ${ }^{1}$.

The learning method in Midwifery Undergraduate Study Program is a Student Centered Learning (SCL), which activities consist of tutorial using seven jump method, clinical skills training, practicum, self-learning, introductory lectures, plenary discussions and expert consultation if necessary. Midwifery education uses a new paradigm, namely the Problem Based Learning (PBL) method, where at the basic level students must master learning techniques and it is hoped that later they will be able to learn continuously throughout their lives and are also required to master communication techniques, ranging from interpersonal communication to communicating with various parties (doctors, other health workers and other non-health workers) either verbally or nonverbally or using information technology. Mastery of this basic level of education is absolute, because it is a prerequisite for a student to be able to continue learning at the next stage.

Block 1.A entitled introduction to midwifery education, is a block that must be learned by students who have just set in the Midwifery Study Program, Faculty of Medicine, Andalas University. Students who take lessons in this block are in a transitional period of the learning process, which is a transitional period between leaving high school and now only in the first level of college. Experience shows that when new students take lessons in higher education, they do not necessarily immediately understand how to study in higher education. This is because when studying in middle school, students do not have the ability to learn how to learn or learn how to think, they tend to adopt superficially, tend to remember rather than understand and they will not become self directed learner. The learning method in higher education uses the adult learning method (higher ordered learning). This method has a different approach, scope, goals and strategies from education in secondary schools. Studying in college, especially medicine program study or obstetrics emphasis on continuing education and lifelong.

Learning is prepared in the form of lectures by experts in the appropriate field, tutorial discussions, skills training and practicum in the laboratory. This block runs for 5 weeks, each week will be discussed 1 module, so this block will discuss 5 modules. In addition to expert lectures, students will carry out clinical skills training. Each week, a plenary discussion will be held with topics tailored to lectures and tutorial materials.

Tutorial learning in block 1.A, which is facilitated by a tutor, is scheduled twice a week (tutorial implementation time is $2 \times 50$ minutes for each meeting) to discuss one scenario. The tutorial discussion is conducted in a structured manner using the seven jump method. Introductory Lectures (KP) are given by experts, which aim to provide guidance to students in learning a topic. The KP must be implemented in that week before the implementation of the plenary discussion by the lecturer whose name is according to the set schedule. Plenary discussion aims to equalize and compare the group learning process to prevent groups from taking the wrong path. The group can pose unsolved problems and the facilitator will guide the discussion. This activity is held every week and is attended by related experts. Clinical skills (KK) are conducted to acquire midwifery skills, ranging from communication, laboratory skills, procedural skills and diagnostic physical skills. KK is held 5 times a week according to a set schedule. Each group is guided by an instructor. At the end of the block, there will be an evaluation of block 1.A theory learning in the form of a CBT exam.

Student assessment is done through an exam at the end of the block. The assessment carried out in measuring student learning achievement in block 1.A consists of several components, namely: tutorial assessment (20\%), practicum (20\%), written exam/ MCQ (60\%). Based on the Decree of the Dean of the Faculty of Medicine, Andalas University number: 3323

/UN16.02D/PP/2018 concerning Academic Regulations, the evaluation system is an assessment of the implementation and success of the learning process including: tutorial activities, clinical skills, group study, independent study and other academic tasks. The evaluation is carried out by the block coordinator, clinical skills coordinator, the head of the study program, the vice dean of the academic division, the Quality Control Group (GKM), and the Medical Education Unit (MEU)monitoring and evaluation division. The assessment system at the academic stage of education uses Absolute Norms, namely Penilaian Acuan Patokan (PAP) which require accurate and mature mastery to achieve the competencies specified in the curriculum. The minimum pass mark for the written test/MCQ is a value of 55. Students are deemed to have passed the block concerned, if they get a complete final 
block score of at least 55, provided that the MCQ block test score is a minimum of 55 .

After participating in block 1.A, it is hoped that they will have a solid cognitive restructuring to be able to achieve core competencies which include a number of knowledge, skills and attitudes, namely lifelong learning skills, skills in communicating as a midwife candidate, understanding moral, ethical and legal aspects in carrying out the profession. Mastery of the material in block 1.A is important, because it will provide provisions for students in shaping the process of thinking and the basis for professional behavior in the future.

The development of methods that will be carried out in this study is to plan the development of effective online learning methods and e-learning assessments to achieve learning outcomes in the form of revised RPB blended learning, e-learning technology media, and the evaluation at the end of the block is done with the Computer Based Test (CBT) on e-learning.

\subsection{Research Purposes}

1. Developing blended learning methods to meet graduate learning outcomes.

2. Revised RPB 1.A blended learning.

3. Increase the use of i-learn by lecturers and students in the learning process.

\section{OUTPUT ACHIEVEMENT STRATEGY}

\subsection{Development Method}

Learning development methods that will be carried out are :

1. Lecturers and students will conduct the learning delivery (learning and teaching) e-learning in several meetings Introductory Lectures (KP) by using the media http://fk.ilearn.unand.ac.id/, zoom app, microsoft team, etc.

2. Every tutorial activity report, independent assignment and a weekly plenary discussion report that has been approved by the tutor and supervisor must be uploaded by students to the i-learn block

1.A page provided http://fk.ilearn.unand.ac.id/ course / view.php? id $=883$

3. The learning content used by the lecturer during the introductory lecture will be uploaded to the i-learn block 1.A page according to the schedule on the week of implementation.

4. A formative assessment will be held at the end of the block in the form of a CBT exam using the i- learn facility of the Faculty of Medicine, Andalas University .

\subsection{Device Used}

The device used in this study uses the i-learn facilities at the Faculty of Medicine, Andalas University which can be accessed on the http://fk.ilearn.unand.ac.id/ page.

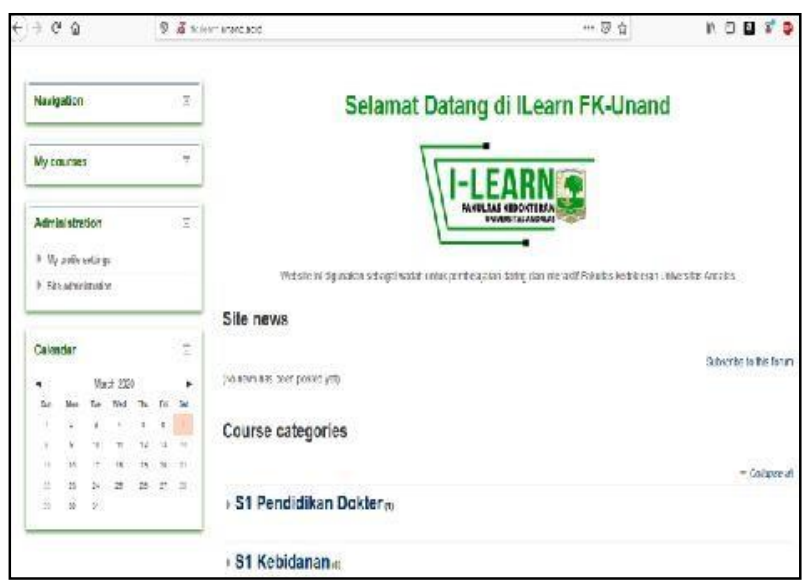

Figure 1. Home Page I-learn FK Unand

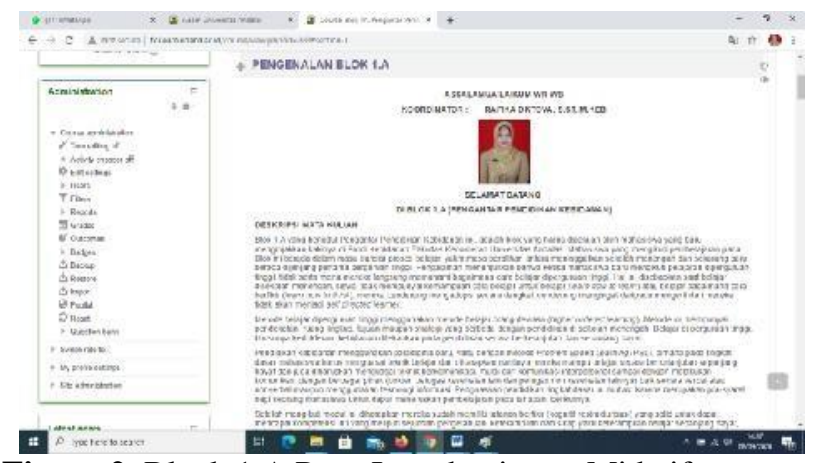

Figure 2. Block 1.A Page Introduction to Midwifery Education

\subsection{Execution Time}

Implementation of block 1.A introduction to midwifery education will be carried out for 5 weeks (effective weeks of learning) plus 1 week provided for formative assessments at the end of the block, which will be carried out at the beginning of the Odd semester of the 2020/2021 (academic year).

\section{DIVISION OF TASKS IN PREVIOUS TEACHING TEACHING}

The division of tasks in the previous teaching team was carried out by distributing a team of lecturers who taught each topic introductory lecture and practicum in block 1.A (introduction to midwifery education). 


\section{IMPLEMENTATION OF ACTIVITIES}

Methods of learning development of blended learning in block 1.A (introduction to midwifery education) who do is to take advantage of i-learn the Faculty of Medicine, Andalas University, which are accessible on the page http://fk.ilearn.unand.ac.id/, with a view as in the following image:

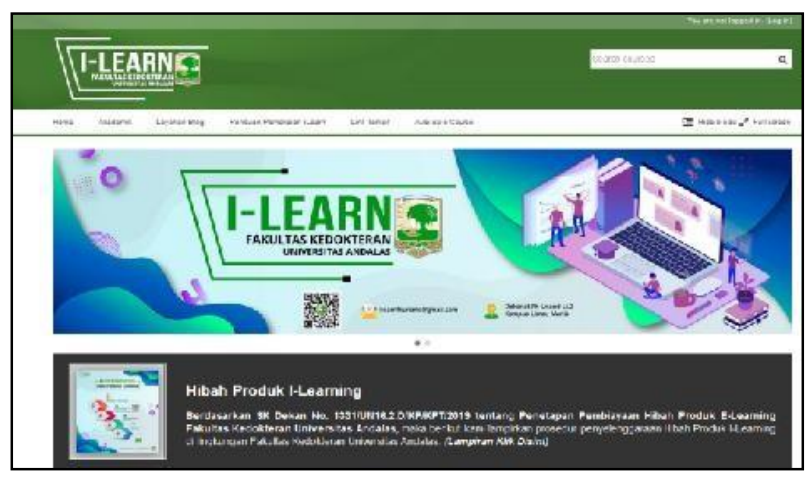

Figure 3. Page I-learn Faculty of Medicine Andalas University

Furthermore, the page can be accessed in the Course Categories "S1 Kebidanan" $>$ "Semester Ganjil 2020/2021" >> "Blok 1.A (Pengantar Pendidikan Kebidanan)" as in the following picture :

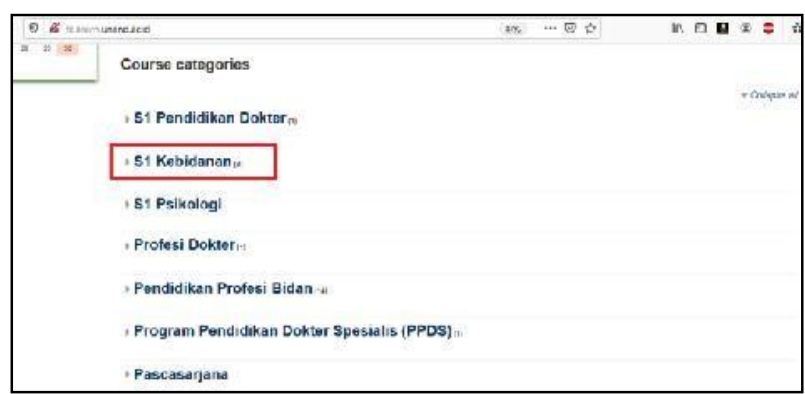

Figure 4. Choice of S1 Midwifery Study Program in the Course Categories

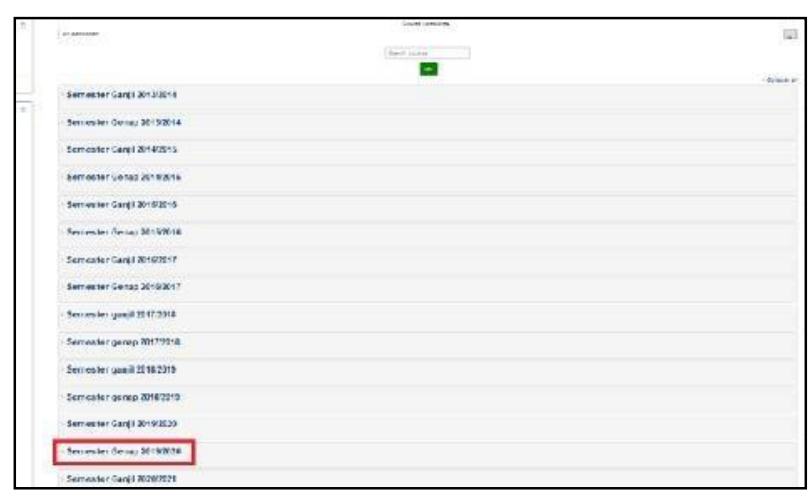

Figure 5. Electives Semester on S1 Midwifery Course

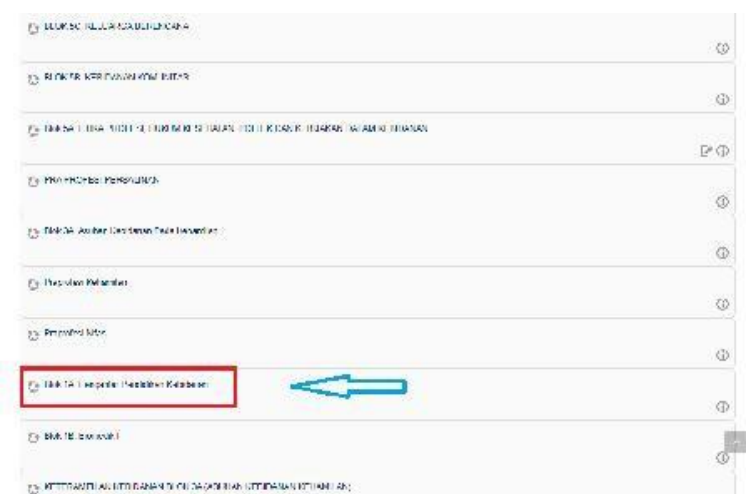

Figure 6. Option Block 1.A in the S1 Midwifery Course So that the display will appear in several sections, including block introduction as shown below:

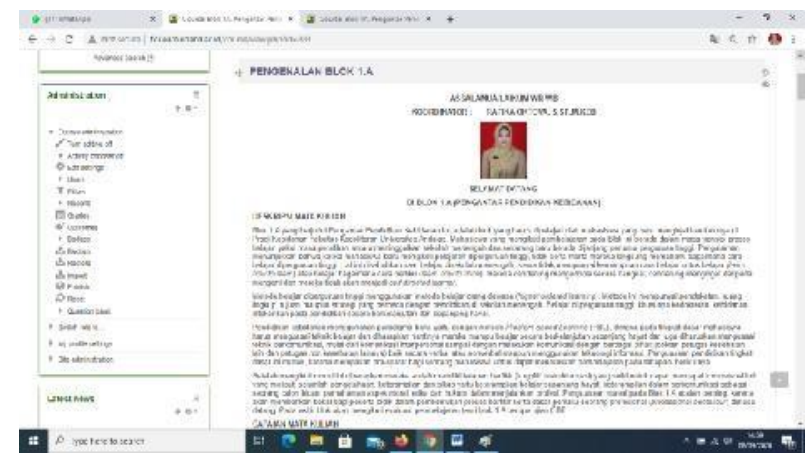

Figure 7. Block 1.A Page View with Several Sections

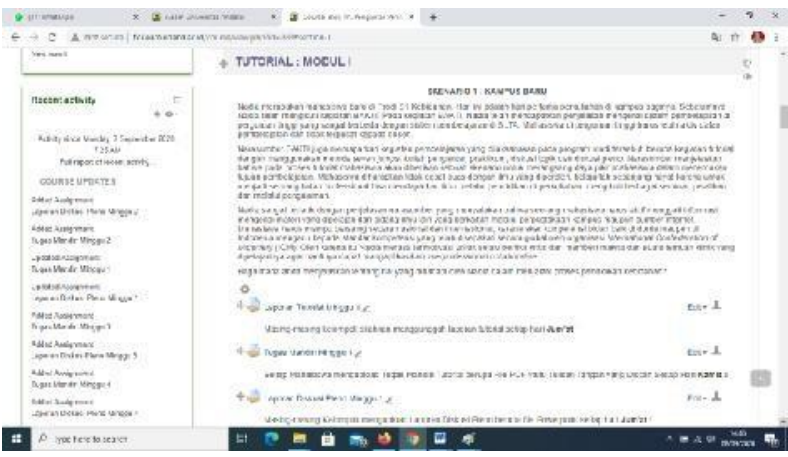

Figure 8. Block 1.A Page View of Week 1 Tutorial Sections (there is a slot for uploading Tutorial Reports, Independent Assignments and Plenary Discussion Reports) 


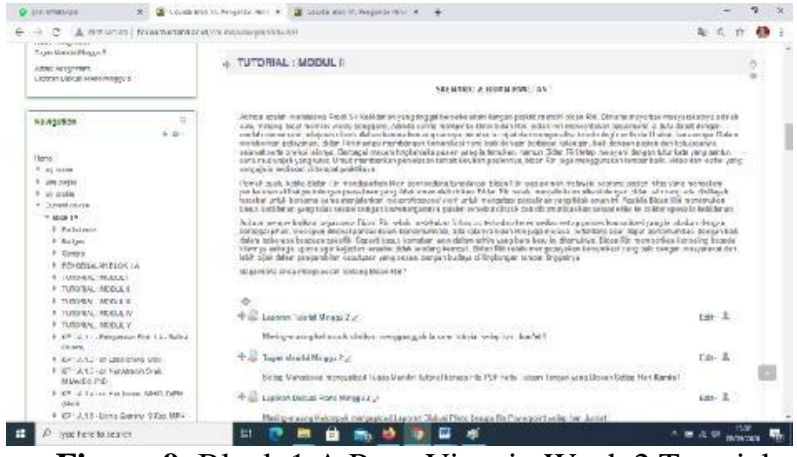

Figure 9. Block 1.A Page View in Week 2 Tutorial Sections (there is a slot for uploading Tutorial Reports, Independent Assignments and Plenary Discussion Reports)

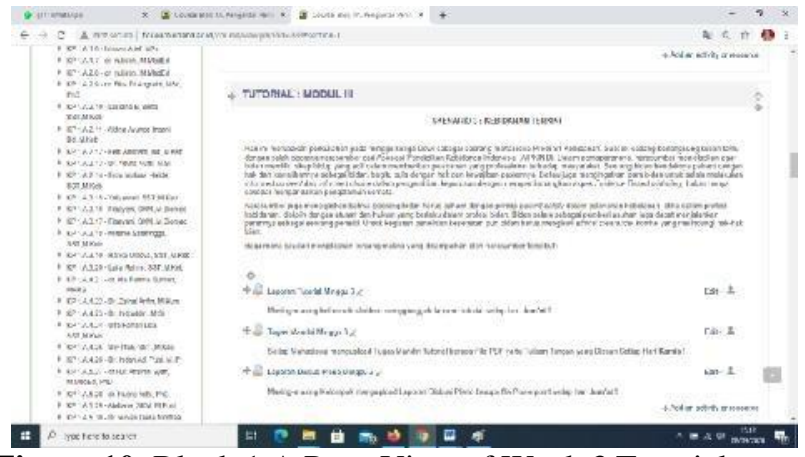

Figure 10. Block 1.A Page View of Week 3 Tutorial Sections (there are slots for uploading Tutorial Reports, Independent Assignments and Plenary Discussion Reports)

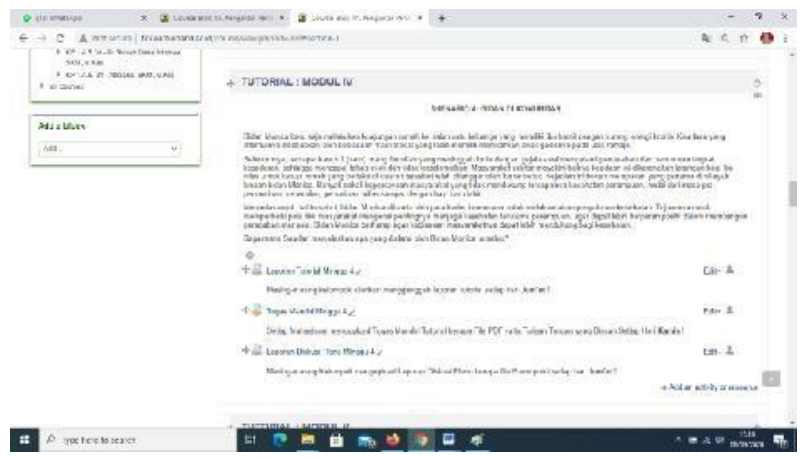

Figure 11. Block 1.A Page View of Week 4 Tutorial Sections (there is a slot upload Tutorial Reports, and Statements Independent Task Plenary Discussion)

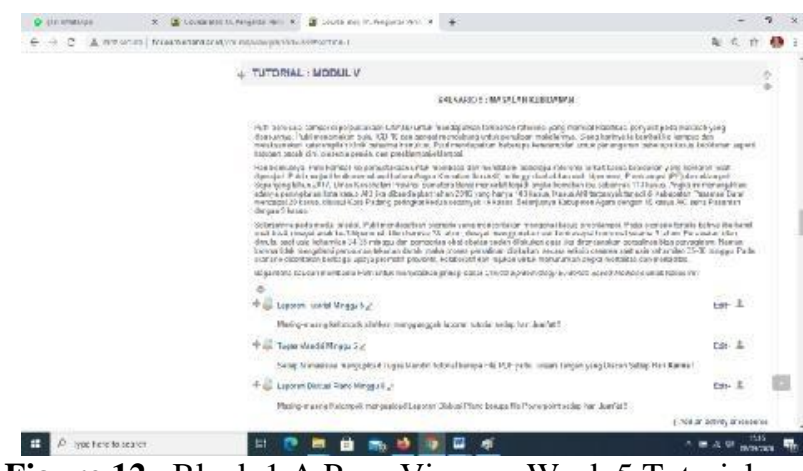

Figure 12 . Block 1.A Page View on Week 5 Tutorial Sections (there is a slot for uploading Tutorial Reports, Independent Assignments and Plenary Discussion Reports)

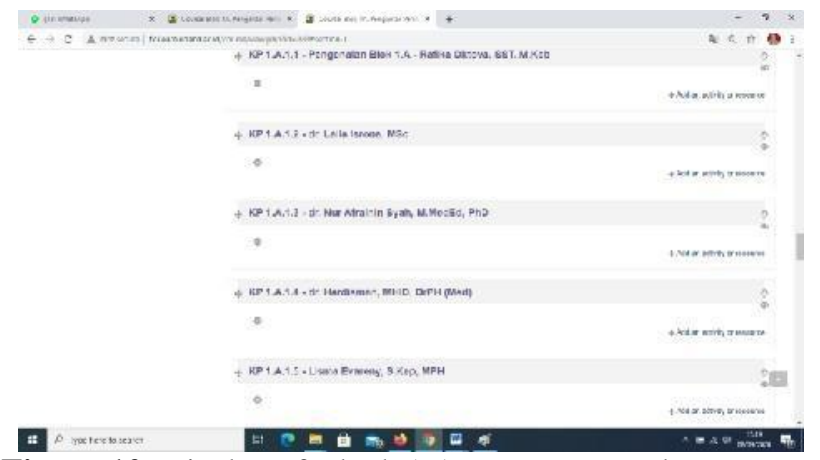

Figure 12. Display of Block 1.A Page on Introductory Lecture Sections

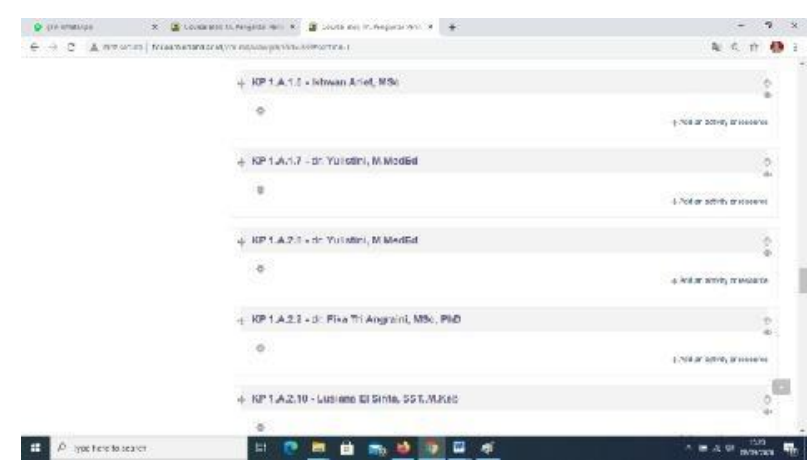

Figure 12. Display of Block 1.A Page on Introductory Lecture Sections

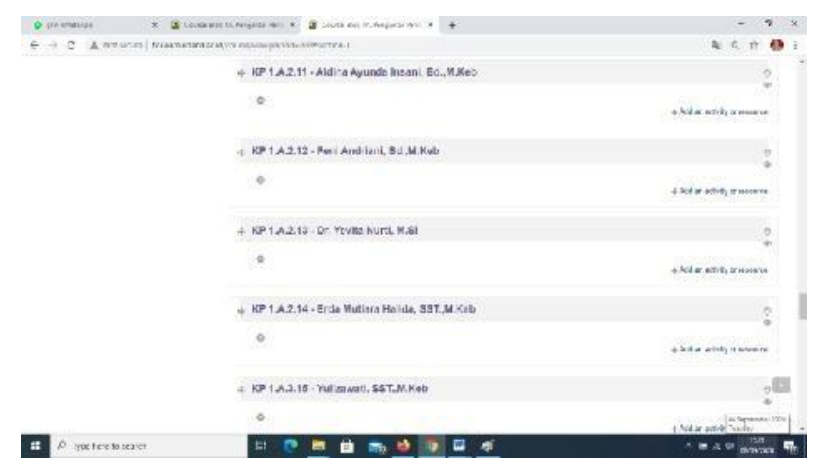

Figure 12. Display of Block 1.A Page on Introductory Lecture Sections 


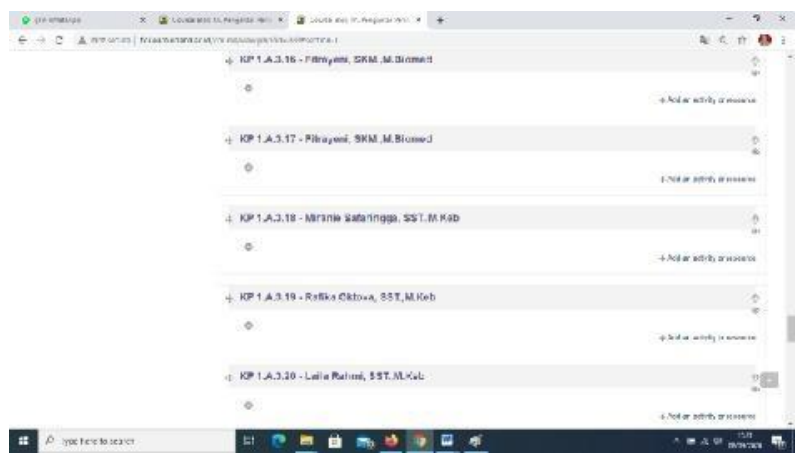

Figure 12. Display of Block 1.A Page on Introductory Lecture Sections

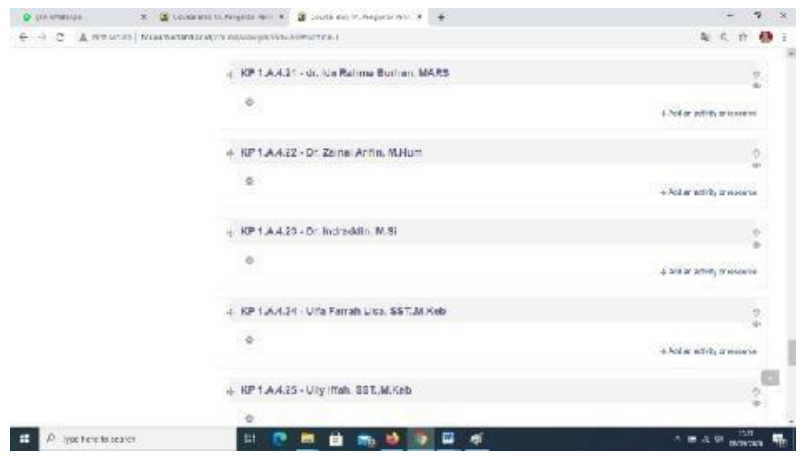

Figure 12. Display of Block 1.A Page on Introductory Lecture Sections

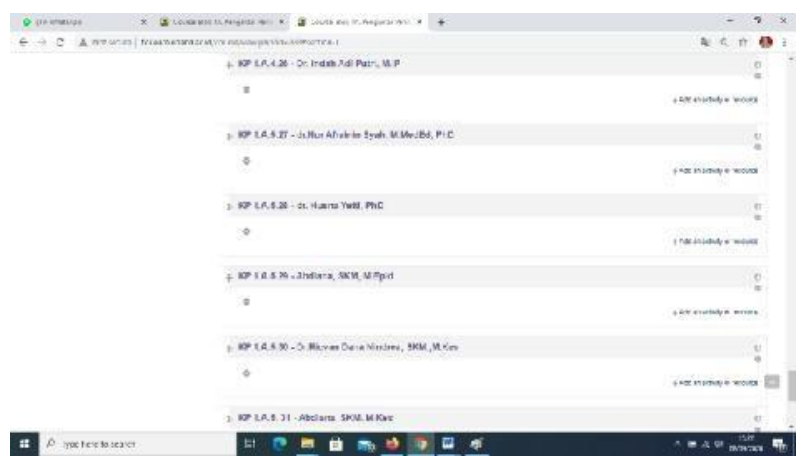

Figure 12. Display of Block 1.A Page on Introductory Lecture Sections

\section{RESULTS}

With the COVID-19 pandemic, there has been a change in learning methods at Andalas University, especially in the Midwifery Undergraduate Study Program, Faculty of Medicine, where learning that was previously carried out conventionally has switched to distance learning by utilizing the Learning Management System (LMS) in the form of the i-learn application http://fk.ilearn.unand.ac.id/. So that it becomes a challenge for lecturers and students with the application of this learning method.

The application of blended learning in block

1.A starts with the block coordinator opening the class for block 1.A then enrolls lecturers and students to the class so that lecturers and students can access it on the link:

http://fk.ilearn.unand.ac.id/course/view.php?id=883
On the block 1.A page, sections are available on block 1.A introduction, which is a block guide upload slot, RPB. Sections tutorial weeks 1-5 are available (there are slots for uploading Tutorial Reports, SelfAssignments and Plenary Discussion Reports). Introductory lecture sections are available (there is a slot for uploading introductory lecture videos according to the topic of each lecturer). Sections forum discussion is available, if any need to be discussed.

Each assignment to be uploaded to i-learn, both groups and individually, is given a time limit every week. So that it can increase student discipline and a sense of responsibility in assignments. At the end of the block, which is the $6^{\text {th }}$ week, an evaluation is carried out with the CBT exam using i-learn.

Blended learning in pandemic COVID-19 moment is alternative method of learning is very effective, efficient way to improve the ability of all students skills to be fun, interest in learning where blended learning to do learning either separately or groups as well as the same time (synchronous) or different (asynchronous).

\section{DISCUSSION}

According to Graham's research, blended learning can be carried out by teachers, lecturers, educational instructors because it has several advantages, namely 1) pedagogical wealth; 2) access to knowledge; 3) social interaction; 4) personal agency; 5) cost effectiveness; and 6) Ease of revision ${ }^{4}$.

Research conducted by Karen Precel, Yoran EshetAlkalai and Yael in the contribution of blended learning components that greatly contribute to learning are assignments (mean 4,72), printed books (mean = 4,54), meeting presentations (mean 4,42), and face-to-face meetings guided by instructors (mean $=4,14$ ). While the results of online learning are contributing to learning $(3,83)$, online books have an average contribution to learning $(3,32)$ even though the contribution is low, almost half of the participants $(46,5 \%)$ stated that they often use them ${ }^{5}$.

Various researches by researchers show that blended learning has a high effect on results compared to online and face-to face learning because blended learning combines or mixes conventional or traditional learning with traditional learning by developing various learning media. Blended learning is an alternative solution for overcoming the weaknesses of online learning and faceto-face learning to produce a series of learning that is effective, efficient and fun for students without throwing away old learning theories ${ }^{6}$.

Advantages of blended learning by Husamah, 2014 were: a) Students flexibility to learn the subject matter independently by utilizing a matter of material available online; b) Students can communicate/discuss with teachers or other learners who do not have to done when in class (face to face); c) Learning activities carried out by students outside of face-to-face hours can be managed and controlled properly by the teacher; d) Teachers can 
add supplementary material through internet facilities; e) Teachers can ask students read the material or take the test before the lesson; f) The teacher can administer quizzes, provide feedback, and make effective use of the test results; g) Students can share files with other students ${ }^{7}$.

The implementation of blended learning in the learning process will help students accommodate learning styles such as visual and audio can have the opportunity to acquire knowledge not only during the learning in the classroom face-to-face with the teacher but they also can gain knowledge when outside the classroom online either through internet and communicate with teachers. Then for students who have a kinesthetic learning style will also be able to gain knowledge when learning in class face-to-face. Therefore, implementing blended learning for strategies for organizing teaching, teaching delivery, and teaching quality will help teachers increase the attractiveness of learning in this $21^{\text {st }}$ era with students who are ready to compete to live in the digital era ${ }^{8}$.

\section{CONCLUSION}

Blended learning during the COVID-19 pandemic is an alternative choice of learning methods that are very effective, efficient to increase student ability to be fun, interest in learning where blended learning can be done separately or in groups and at the same time (synchronous) or different (asynchronous).

\section{REFERENCES}

[1] Handoko dan Waskito, 2018. Blended Learning: Konsep dan Penerapannya. Lembaga Pengembangan Teknologi Informasi dan Komunikasi (LPTIK) Universitas Andalas. Padang.

[2] Ajeffrey, L.M. Milne, J, Suddaby. J.\& Higgins,"Blended Learning: How Teachers Balance the Blend of Online and Classroom Components", Journal Of Information Technology Education:Research, Vol, 13. No 2. 2014.

[3] Rusman, dkk. 2011. Pembelajaran Berbasis Teknologi Informasi dan Komunikasi, Jakarta: PT Raja Grafindo Persada.

[4] Graham, Charles R. 2004. Blended Learning Systems: Definition, Current Trends, and Future Directions. Dalam Bonk, C.J. \& Graham, CR.Eds. Impress" Handbook Of Blended Learning:Global Persepektives, local designs. San Fransisco CA: Pfeiffer Publishing

[5] Karen precel, Yoram Eshet Alklai and Yael "Pedagogical And Desain Aspect Of Blended Learning Course". International Review of Research in Open and Distance Learning. Vol.
10,No. 2. ISSN: 1492- 3831 April 2009

[6] Abdullah, Walib, Model Blended Learning dalam Meningkatkan Efektifitas Pembelajaran. Jurnal Pendidikan dan Manajemen Islam Volume 7, Nomor 1, Juli 2018

[7] Husamah. 2014, Pembelajaran Bauran (Blended Learning) Terampil Memadukan Keunggulan Pembelajaran Face-To-Face, E-learning OfflineOnline, dan Mobile Learning. Jakarta: Prestasi Pustaka.

[8] Wardani, dkk. Daya Tarik Pembelajaran Di Era 21 Dengan Blended Learning. JKTP Volume 1, Nomor 1, April 2018 